\title{
Model Penelitian dan Pengembangan Materi Ajar BIPA (Bahasa Indonesia bagi Penutur Asing)
}

\section{Defina Defina}

Institut Pertanian Bogor

defina@ipb.ac.id

\begin{tabular}{|c|c|}
\hline Article info & A B S T R A C T \\
\hline $\begin{array}{l}\text { Article history: } \\
\text { Received: 06-08-2108 } \\
\text { Revised : 10-11-2018 } \\
\text { Accepted: 25-12-2018 }\end{array}$ & $\begin{array}{l}\text { The objectives of this research are (1) to analyze the development model of } \\
\text { Indonesian language teaching materials for foreign speakers and (2) combine } \\
\text { the existing models. The analysis of this theory based on the results of research } \\
\text { and development has been undertaken by BIPA IPB. The research had been } \\
\text { conducted from August } 2015 \text { to Februrai } 2017 \text {. Eight models were the research } \\
\text { objects to analyze, namely a) ADDIE models, b) Dick, Carey, and Carey } \\
\text { models, c) Borg and Gall models, d) ASSURE models, Kemp models, f) } \\
\text { Tomlinson models, g) Brown models, and h) Jolly and Bolitho models.The } \\
\text { research result shows models that have been modified in three main parts, } \\
\text { namely 1) preparation, 2) planning, and 3) development-evaluation. These three } \\
\text { parts can be broken down into } 17 \text { sections, such as 1) curriculum, 2) needs } \\
\text { analysis, 3) syllabus, 4) text collection, 5) text selection, 6) material creation, 7) } \\
\text { draft I, 8) preparation of test questions, 9) one to one test, 10) revision I, 11) } \\
\text { draft II, 12) small group trial, 13) revision II, 14) draft III, 15) effectiveness test, } \\
\text { 16) revision III, and 17) final product. The conclusion is that each model has its } \\
\text { advantages and disadvantages. The development of Indonesian language } \\
\text { teaching material models for foreign speakers can be undertaken by combining } \\
\text { development research models that have been formulated by experts. }\end{array}$ \\
\hline
\end{tabular}

Tujuan penelitian ini adalah untuk menganalisis model pengembangan materi ajar bahasa Indonesia bagi penutur asing dan mengombinasikan model-model yang ada. Analisis teori ini berdasarkan hasil penelitian dan pengembangan yang telah dilakukan di BIPA IPB. Penelitian dilakukan sejak Agustus 2015-Februari 2017. Objek yang dianalisis ada delapan model: a) model ADDIE, b) model Dick, Carey, dan Carey, c) model Borg dan Gall, d) model ASSURE, e) model Kemp, f) Tomlinson, g) Brown, dan h) Jolly dan Bolitho. Hasilnya, dari delapan model yang dianalisis, dapat dirumuskan model yang telah dimodifikasi. Ada tiga bagian utamanya, yaitu 1) persiapan, 2) perencanaan, dan 3) pengembangan-evaluasi. Dari 3 bagian itu dapat diuraikan menjadi 17 bagian: 1) kurikulum, 2) analisis kebutuhan, 3) silabus, 4) pengumpulan teks, 5) pemilahan teks, 6) pengkreasian materi, 7) draf I, 8) penyusunan soal tes, 9) uji one to one, 10) revisi I, 11) draf II, 12) uji coba kelompok kecil, 13) revisi II, 14) draf III, 15) uji efektivitas, 16) revisi III, dan 17) produk final. Simpulannya adalah setiap model itu memiliki kelebih dan kekurangan. Pengembangan model materi ajar bahasa Indonesia bagi penutur asing dapat dilakukan dengan mengombinasikan model-model penelitian pengembangan yang sudah dirumuskan para pakar.

Copyright $\odot 2018$ Institut Agama Islam Negeri Syekh Nurjati Cirebon All rights reserved

\section{PENDAHULUAN}

Untuk meningkatkan kualitas hasil pembelajaran bahasa Indonesia bagi penutur asing (BIPA), diperlukan media ajar yang sesuai dengan kebutuhan peserta ajar. Sebagai pengajaran bahasa kedua, BIPA perlu mempertimbangkan faktor-faktor pembelajar 


\section{Indonesian Language Education and Literature e-ISSN: 2502-2261 \\ http://www.syekhnurjati.ac.id/jurnal/index.php/jeill/ \\ Vol. 4, No. 1, Desember 2018, 36 - 51}

(Zahidin \& Mulyaningsih, 2016). Hal ini juga harus diterapkan pada media pembelajaran yang digunakan. Media ajar ini menurut Smaldino et. al (2006) "A medium (plural,media) is means of communication and source of information." Jadi, media adalah sumber informasi. Lebih lanjut dikatakan bahwa media itu termasuk video, televisi, diagram, materi yang dicetak, program komputer, dan pengajar. Brinton (2001) mengatakan, "media-of technological innovations in language teaching, of mecanical paraphernalia, and of glossy, polished audiosual aids." Dengan demikian, cakupan media pembelajaran tidak hanya berupa kertas yang dicetak, seperti buku, tetapi juga mencakup teknologi. Buku sebagai bahan ajar, disebut Brown (2007) sebagai buku teks. Buku teks itu adalah jenis teks dan buku yang digunakan dalam kurikulum pendidikan. Terdapat dua jenis buku teks: 1) buku sumber bagi pengajar dan 2) buku peserta didik.

Definisi materi ajar yang diungkapkan Brown tersebut, khususnya, adanya latihan yang dilakukan di dalam kelas, juga terdapat pada definisi yang diberikan oleh Harwood. Akan tetapi, Harwood lebih menjelaskan lagi bahwa materi ajar itu berisi teks dan tugastugas belajar yang diberikan kepada peserta didik. Teks dan tugas-tugas itu dapat berbentuk kertas (cetak), audio, dan visual.

Selanjutnya, materi ajar itu mencakup teks berbentuk cetak (kertas), audio, dan visual ini juga diungkapkan oleh Tomlinson (2007). Materi ajar, menurut Richards (2001), merupakan komponen utama dalam sebuah pembelajaran bahasa. Dari keempat konsep materi ajar tersebut dapat disimpulkan tiga hal. Pertama, materi ajar adalah semua yang digambarkan atau dideskripsikan dalam proses pembelajaran di kelas. Kedua, materi ajar berisi teks dan tugas-tugas. Ketiga, materi ajar dapat berupa cetak (buku), audio, dan visual.

Penelitian pendidikan dan pengembangan menurut Borg dan Gall (1983) juga sering disebut penelitian berbasis pengembangan (research-based development). Borg dan Gall mengatakan, Educational research and development $(R \& D)$ is a process used to develop and validate educational products. Artinya, penelitian dan pengembangan mestilah melalui sebuah proses. Proses itu mencakup pengembangan dan validasi sebuah produk dalam bidang pendidikan. Penelitian dan pengembangan menurut Gay et al. (2011) adalah sebuah proses penelitian yang berdasarkan pada kebutuhan konsumen dan pengembangan produk ini sesuai dengan analisis kebutuhan. Penelitian dan pengembangan in bertujuan 


\section{Indonesian Language Education and Literature e-ISSN: 2502-2261 \\ http://www.syekhnurjati.ac.id/jurnal/index.php/jeill/ \\ Vol. 4, No. 1, Desember 2018, 36 - 51}

mengembangkan produk yang efektif untuk digunakan di sekolah. Salah satu contohnya adalah materi ajar.

Hal senada juga diungkapkan pakar penelitian dan pengembangan di Indonesia. Setyosari (2012) mengatakan bahwa penelitian dan pengembangan adalah suatu proses atau langkah-langah untuk mengembangkan suatu produk baru atau menyempurnakan produk yang telah ada, yang dapat dipertanggungjawabkan. Produk itu dapat berupa perangkat keras, seperti buku dan modul. Dari konsep ini dapat dilihat bahwa produk yang dikembangkan itu tidak mesti produk yang baru, tetapi dapat produk lama agar produk lama ini lebih sempurna. Selanjutnya, Sugiono (2014) mengatakan bahwa research and development $(\mathrm{R} \& \mathrm{D})$ adalah metode penelitian yang digunakan untuk menghasilkan produk tertentu. Lalu, diuji keefektifan produk tersebut. Konsep yang dikemukakan Sugiono ini sama dengan konsep yang dikemukakan Gay et al., yakni sama-sama sebuah proses menghasilkan produk dan produk itu harus efektif.

Jadi, dari konsep-konsep tentang penelitian dan pengembangan yang dikemukakan oleh para pakar, terdapat perbedaaan dan persamaan. Akan tetapi, jika konsep ini digabungkan, konsep itu akan saling melengkapi. Pertama, penelitian pengembangan adalah penelitian yang bertujuan menghasilkan sebuah produk atau sebuah prosedur. Kedua, produk itu dapat berupa produk baru dan dapat pula berupa pengembangan produk yang lama. Ketiga, produk yang dihasilkan mesti dapat dipertanggungjawabkan. Keempat, pengembangan produk itu mesti sesuai dengan kebutuhan. Kelima, produk itu mesti divalidasi. Keenam, produk itu efektif.

Sesuai dengan konsep di atas, dalam penelitian ini, batasan konsep yang digunakan adalah mengombinasikan konsep yang diberikan oleh Borg dan Gall, Gay et al., dan Sugiono. Batasan konsep itu adalah sebuah penelitian untuk menghasilkan sebuah produk baru yang dapat dipertangungjawabkan dan telah melalui tahap pengembangan sesuai dengan kebutuhan, divalidasi, dan diuji keefektifannya. Penelitian yang berfokus pada kajian teori yang menganalisis model-model penelitian dan pengembangan belum banyak dilakukan. Sehubungan dengan hal itu, tujuan penulisan ini adalah menganalisis modelmodel penelitian dan pengembangan yang sudah dirumuskan oleh pakar-pakarnya dan mengombinasikan model-model yang ada.

\section{METODE}


Penelitian ini adalah bagain dari penelitian dan pengembangan (R\&D). Penelitian dilakukan di BIPA IPB, dari Agustus 2015--Februari 2017. Pada penelitian ini ada delapan model yang dianalisis dan dikombinasikan. Kedelapan model itu adalah a) model ADDIE, b) model Dick, Carey, dan Carey, c) model Borg dan Gall, d) model ASSURE, e) model Kemp, f) Tomlinson, g) Brown, dan h) Jolly dan Bolitho.

\section{HASIL DAN PEMBAHASAN}

Ada dua hal yang diuraikan pada bagian ini. Kedua hal itu adalah 1) analisis delapan model penelitian dan pengembangan materi ajar dan 2) model yang dikombinasikan. Ada delapan model yang dibahas pada bagian ini. Kedelapan model itu adalah a) model ADDIE, b) model Dick, Carey,dan Carey, c) model Borg dan Gall, d) model ASSURE, e) model Kemp, f) Tomlinson, g) Brown, dan h) Jolly dan Bolitho. Kedelapan model penelitian pengembangan ini adalah model penelitian dan pengembangan pembelajaran dan pembelajaran bahasa, juga termasuk pengembangan materi ajar.

\section{Model ADDIE}

ADDIE menurut Branch (2009) adalah singkatan dari Analize, Design, Develop, Implement, and Evaluate. Model ini adalah sebuah konsep pengembangan produk pembelajaran. Produk ini berorientasi kepada kebutuhan peserta didik. Artinya, konsep ADDIE diaplikasikan untuk menyusun rancangan pembelajaran berdasarkan kinerja (performance) peserta didik. Hal yang paling mendasar pada aplikasi ini adalah student center 'berpusat pada peserta didik', inovatif, otentik, dan hal yang menginspirasi.

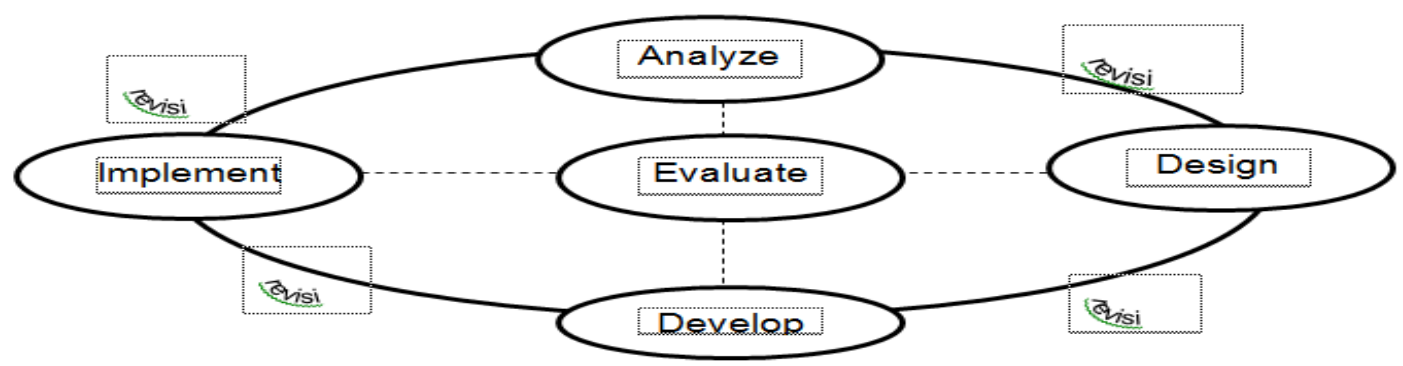

Gambar 1. Konsep ADDIE dalam Branch (2009:2), dalam Richey, Klein, dan Tracey (2001: 19), serta Gustafson dan Branch (2002:3) 


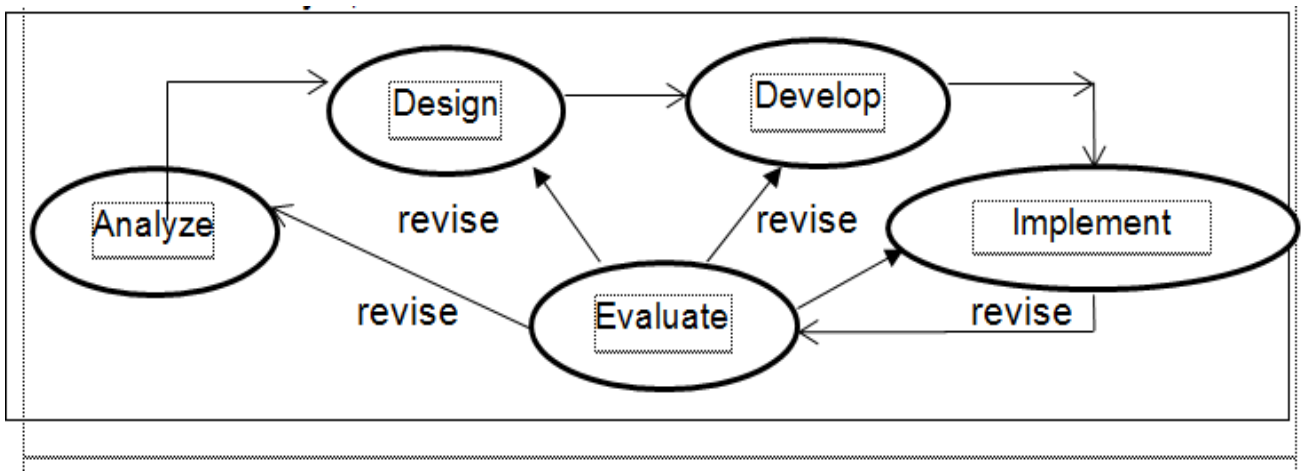

Gambar 2. Model ADDIE yang disusun Gagne et. al. (2005:21)

Dari dua gambar tersebut dapat dilihat bahwa ada lima langkah dasar atau fase dalam konsep ADDIE, yakni 1) analisis, 2) perencanaan, 3) pengembangan, 4) penerapan, dan 5) evaluasi. Setiap langkah ini saling berkaitan. Ada beberapa perbedaan pada bagan yang disusun Branch dengan yang disusun Gagne et. al. Pada bagian evaluasi, bagan yang disusun Gagne et. al. menggunakan garis yang jelas, untuk menghubungkan antara evaluasi dengan analisis, perencanaan, pengembangan, dan implementasi. Sebaliknya, Brach menggunakan garis putus-putus untuk menghubungkan antara evaluasi dengan analisis, perencanaan, pengembangan, dan implementasi.

Model ADDIE yang memiliki lima komponen ini dibagi lagi menjadi subsubkomponen (Branch, 2009). Dari lima komponen dasar ini dihasilkan 21 subkomponen: 1) Analisis (validasi kesenjangan kinerja, menentukan tujuan pembelajaran yang akan dicapai, mengonfirmasi peserta didik, identifikasi sumber-sumber yang diperlukan, menentukan sistem penyampaian/media yang baik, dan menyusun rencana pengelolaan proyek; rancangan/desain (menyusun daftar tugas, menyusun tujuan khusus kinerja,menghasilkan strategi tes, dan merevisi yang telah dilakukan); pengembangan (mengembangkan isi, memilih/mengembangkan media pendukung, mengembangkan panduan untuk peserta didik, mengembangkan panduan untuk pengajar, mengadakan revisi formatif, dan melakukan tes uji coba); implementasi (mempersiapkan peserta didik dan mempersiapkan pengajar); evaluasi (menentukan kriteria evaluasi, memilih alat evaluasi, dan melakukan evaluasi). Model ini lebih ditekankan pada desain pembelajaran dan kurang tepat digunakan untuk desain materi ajar.

\section{Model Dick, Carey dan Carey}

Model Dick, Carey dan Carey disusun atau dikembangkan oleh Walter Dick, Lou Carey, dan James O. Carey. Menurut Pribadi (2010:98), model ini disusun berdasarkan 


$$
\begin{gathered}
\text { Indonesian Language Education and Literature } \\
\text { e-ISSN: 2502-2261 } \\
\text { http://www.syekhnurjati.ac.id/jurnal/index.php/jeill/ } \\
\text { Vol. 4, No. 1, Desember 2018, } 36 \text { - } 51
\end{gathered}
$$

pemikiran dan karya besar Robert M. Gagne. Model ini adalah model prosedural yakni mesti bertahap. "Some are visually represented to appear as linear, step-by-step procedures (see, for example, Dick, Carey\&Carey 2009) (Richey, Klein, dan Tracey, 2001: 20)."

Dalam model Dick, Carey dan Carey terdapat sepuluh komponen. Kesepuluh komponen itu adalah 1) indetify instructional goal(s) 'identifikasi tujuan pembelajaran', 2) conduct instructional analysis'melakukan analisis pembelajaran', 3) analyze learners and contexts 'analisis peserta didik dan konteks', 4) write performance objectives 'menyusun tujuan kinerja khusus', 5) develop assessment instruments 'mengembangkan tes acuan forma', 6) develop instructional strategy 'mengembangkan strategi pembelajaran', 7) develop and select instructional material 'mengembangkan dan memilih bahan pembelajaran', 8) design and conduct formative evaluation of Instruction 'merancang dan melakukan evaluasi fomatif', 9) revise instruction 'melakukan revisi pembelajaran', 10) design and conduct summative evaluation 'merancang dan melakukan evaluasi sumatif' (Dick, Carey dan Carey, 2009:6-8). Hal ini dapat dilihat dari bagan berikut.

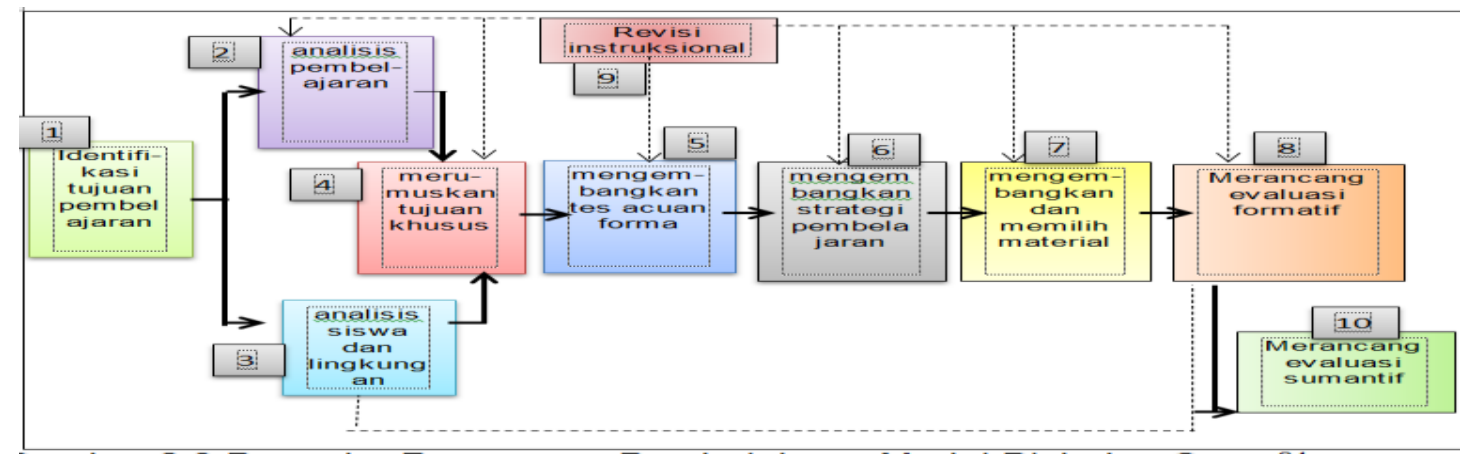

Gambar 3. Prosedur Rancangan Pembelajaran Model Dick, Carey dan Carey (2009:1)

Dari uraian dan bagan tentang model Dick, Carey dan Carey, dapat dilihat kelebihan dan kekurangan model ini. Kelebihan model ini adalah terperinci dan melalui prosedur. Artinya, seorang pengembang tidak dapat melakukan satu tahap lebih tinggi sebelum menyelesaikan tahap di bawahnya (sebelumnya). Selain itu, pada setiap tahap dapat dilakukan revisi. Seorang pengembang juga dapat meminta masukan dari pakar, yakni dengan adanya penilaian pakar: "Reactions of the subject-matter expert. It is the responsibility of this person to verify that the content of the module is accurate and current (Dick, Carey dan Carey, 2009).” Sebaliknya, kekurangan model ini adalah tahap pertama sudah langsung dirumuskan tujuan tanpa terlebih dahulu melakukan penelitian awal, 
terutama penelitian awal tentang kondisi materi ajar yang ada. Selain itu, fokus model ini bukan hanya materi ajar, melainkan juga strategi pembelajaran.

\section{Model Borg dan Gall}

Model Borg dan Gall dikembangkan oleh Walter R. Borg dan Meredith D. Gall (1983). Model ini juga merupakan model prosedural (cycle). Model awal yang dikembangkan 10 tahap atau proses yang mesti dilakukan. Kesepuluh langkah itu adalah sebagai berikut.

1) Research and information collecting 'penelitian dan pengumpulan data'. Pada tahap ini pengembang mencari informasi awal terkait dengan pelaksanaan pembelajaran, termasuk di dalamnya kondisi ruang belajar. Tahap ini dilakukan bersamaan dengan tahap ke-1 model Dick, Carey, dan Carey, yakni identifikasi kebutuhan pembelajaran. Selain itu, pada tahap ini dapat dilakukan pengumpulan dokumen terkait dengan kondisi silabus dan materi ajar yang ada, kondisi peserta didik dan pengajar. Tahap ke-1 ini sudah mencakup tahap ke-1, ke-2, dan ke-3 model Dick, Carey dan Carey.

2) Planning 'Perencanaan'. Tahap ini merupakan penggabungan dari tahap ke4 dan ke5 dari model Dick, Carey dan Carey.

3) Develop preliminary form of product 'pengembangan produk awal'. Tahap ini merupakan tahap yang menghasilkan draf/prototipe pertama. Sehubungan dengan penelitian pengembangan model materi ajar bahasa Indonesia, dikembangkan materi pembelajaran bahasa Indonesia yang berisi tugas-tugas dan tes formatif, serta dikembangkan buku pegangan guru.

4) Preliminary field testing 'Tes dasar awal'. Evaluasi formatif itu adalah uji coba awal one-to one. Pada model Dick, Carey dan Carey tidak membutuhkan peserta didik yang banyak.Tahap ini dapat dilakukan jika model yang dikembangkan akan diterapkan di sekolah atau perguruan tinggi yang memiliki kesamaan kurikulum. Setelah uji tahap awal dilaksanakan, disebarkan kuesioner dan diikuti dengan wawancara.

5) Main product revision 'revisi produk'. Pada tahap ini dilakukan revisi produk.

6) Main field testing 'uji coba lanjutan'. Tahap ini tidak dapat diterapkan untuk pengembangan materi ajar tujuan khusus karena akan sulit mencari sekolah yang memiliki kurikulum yang sama. Jika dibandingkan dengan tahap evaluasi formatif 
yang ada dalam model Dick, Carey, dan Carey, revisi ke-2 untuk menghasilkan draf ke-3 dapat dilakukan dengan uji kelompok kecil/ uji terbatas.

7) Operational product revision 'revisi produk lanjutan'. Pada tahap ini dilaksanakan revisi produk berdasarkan hasil uji coba lapangan dan analisis data.

8) Operational field testing 'uji coba lapangan'. Saat dilakukan uji lapangan, dapat dinilai efektivitas produk.

9) Final product revision 'revisi produk akhir'. Pada tahap ini dilaksanakan revisi akhir, yakni berdasarkan hasil uji coba lapangan ke-3 dan analisis data.

10) Dissemination and implementation 'diseminasi dan implementasi'. Peneliti melakukan diseminasi dan penyebaran kepada berbagai pihak, baik melalui publikasi maupun cara-cara difusi lainnya.

Dari uraian tahapan model Borg dan Gall tersebut, dapat dilihat bahwa model ini hampir sama dengan model Dick, Carey, dan Carey, yakni sama-sama memiliki kelebihan dalam hal proses yang bertahap. Tahapan itu dimulai dari identifikasi kebutuhan dan diakhiri dengan diseminasi atau evaluasi sumatif. Akan tetapi, model Borg dan Gall membutuhkan waktu yang panjang dan cakupan uji coba yang terlalu luas, yakni diujicobakan pada 30 sekolah. Sebaliknya, model ini juga ada kelemahan, yakni tidak adanya penilaian pakar.

\section{Model ASSURE}

Model ASSURE menurut Shambaugh dan Magliaro (2006) adalah sebuah model yang memilih dan mengimplementasikan teknologi serta media pembelajaran dalam aktivitas belajar. Menurut Smaldino, Lowther, dan Russell (2006), “model ASSURE ini menggunakan proses yang bertahap untuk mengkreasikan pelajaran sehingga lebih efektif dengan mengintegrasikan penggunaan teknologi dan media sehingga dapat meningkatkan kemampuan siswa". Selanjutnya, Pribadi (2010) mengatakan bahwa model ini dikembangkan oleh Sharon E. Smaldino, James D. Russel, Robert Heinich, dan Michael Molenda pada tahun 2005.

Jadi, sesuai dengan namanya, ada enam langkah penting dalam model desain pembelajaran ASSURE. Keenam langkah itu sesuai dengan urutan singkatan dari nama model ASSUE, yakni 1) analyze learner 'analisis peserta didik', 2) state objectives 'menentukan tujuan', 3) select methods, media, and materials 'memilih metode, media dan materi', 4) ultilize technology, media, and materials 'memanfaatkan teknologi, media dan 
Indonesian Language Education and Literature

e-ISSN: 2502-2261

http://www.syekhnurjati.ac.id/jurnal/index.php/jeill/

Vol. 4, No. 1, Desember 2018, 36 - 51

materi', 5) require learners participation 'membutuhkan partisipasi peserta didik', dan 6) evaluate and revise 'evaluasi dan perbaikan'. Fokus model ini tidak hanya satu, tetapi tiga aspek: media/teknologi, metode, dan bahan ajar. Untuk pengembangan materi ajar, tahapan pemilihan media, metode, dan materi (tahap ke-3) dapat digunakan. Fokusnya hanya kepada materi ajar. Materi ajar yang dikembangkan dapat memodifikasi materi yang sudah ada.

\section{Model Kemp}

Model Kemp dikembangkan oleh Jerol E. Kemp dan kawan-kawan. Model ini berbentuk lingkaran (cycle) yang berarti berkelanjutan. “...while others emphasize fluidity and the iterative nature of the process (see, for example, Morrison, Ross \& Kemp, 2007) (Richey, Klein, dan Tracey, 2001).” Ada empat komponen sangat mendasar dalam model Kemp. Keempat komponen itu adalah sebagai berikut: (1) learners, (2) method, (3) objectives, dan (4) evaluation (Morrison et. al, 2007). Dari empat komponen besar tersebut dapat dilihat bahwa model ini berfokus pada pembelajaran secara umum.

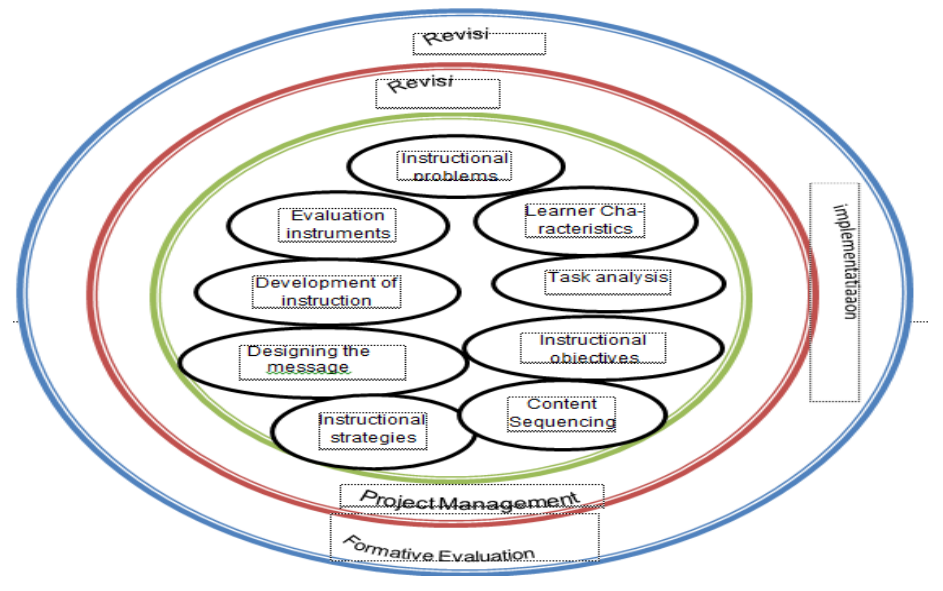

\section{Gambar 4. Model Kemp menurut Morrison et. Al (2007)}

Dari gambar model Kemp tersebut dapat dilihat bahwa model ini berupa siklus. Siklus itu dimulai dari tahap ke-1 hingga ke tahap ke-9. Kesembilan komponen itu adalah 1) instructional problem 'permasalahan pembelajaran', 2) learner characteristics 'karakteristik peserta didik', 3) task analysis 'menganalisis tugas', 4) instructional objectives 'tujuan pembelajaran khusus', 5) content sequencing 'sistematika penyampaian materi', 6) instructionalstrategies 'strategi pembelajaran', 7) designing the message 'merancang penyampaian materi', 8) development of the instruction 'mengembangkan pembelajaran', 9) evaluation instruments 'instrumen evaluasi'

\section{Model Tomlinson}




$$
\begin{gathered}
\text { Indonesian Language Education and Literature } \\
\text { e-ISSN: 2502-2261 } \\
\text { http://www.syekhnurjati.ac.id/jurnal/index.php/jeill/ } \\
\text { Vol. 4, No. 1, Desember 2018, 36 - } 51
\end{gathered}
$$

Dalam merumuskan model pengembangan materi ajar, Tomlinson (2007) membuat dua kerangka, yaitu text-driven dan task-driven. Text-driven adalah ideal untuk mengembangkan buku ajar dan materi tambahan di kelas. Task-driven adalah untuk tugas mandiri di kelas. Untuk menerapkan text-driven dalam pengembangan materi ajar, ada delapan langkah yang mesti dilakukan oleh seorang pengembang: 1) pengumpulan teks (text collection), teks ini dapat diambil dari berbagai sumber, seperti karya sastra, lagu, surat kabar dan majalah, buku nonfiksi, radio, acara televisi, dan film; Pemilihan teks (text selection; 2) pencobaan teks (text experience); 3) aktivitas kesiapan (readiness activities); 4) aktivitas terkait pengalaman (experiential activities); 5) aktivitas asupan tanggapan (intake response activities); 6) aktivitas pengembangan (development activities), pada kegiatan ini, peserta didik diberikan kesempatan untuk meciptakan bahasa yang bermakna berdasarkan pemahaman mereka terhadap teks; serta 7) aktivitas tanggapan masukan (input response activities).

\section{a. Model Brown}

Dalam mengembangkan materi ajar, Brown (1995) mengemukakan bahwa ada tujuh fase yang dapat dilakukan. Ketujuh fase itu adalah sebagai berikut.

1) Overall Curriculum 'kurikulum'. Pada bagian ini, dilakukan dua hal: a) approach 'pendekatan', dan b) syllabus 'silabus'. Pendekatan yang dimaksud adalah merumuskan kerangka teori lalu merevisinya. Selanjutnya, disusun silabus dan direvisi.

2) Needs, analisis kebutuhan peserta didik dan ditetapkan kebutuhan peserta didik. Lalu, dilakukan revisi.

3) Goal and objective. Pada tahap ini ditetapkan tujuan umum (goal) dan tujuan khusus (objective). Lalu, dilakukan revisi; dilakukan setelah analisis kebutuhan.

4) Test. Pada tahap ke-4 ini dilakukan proficiency atau placement. Dengan demikian, diperoleh tingkatan (level) kemampuan peserta didik secara keseluruhan. Selain itu, juga dilakukan diagnosis dan prestasi (achievement) peserta didik. Dengan demikian, akan diperoleh kepatutan tujuan khusus (objective). Artinya, pengembang sudah mengetahui kemampuan berbahasa peserta didik.

5) Creating 'mengkreasikan'. Pada tahap ini, ada enam hal yang mesti diperhatikan: (a) kerelaan pengajar untuk menjadi pengembang materi; (b) menjamin semua pengembang materi memiliki foto kopi dokumen, seperti deskripsi program, tujuan umum dan khusus, materi cetak biru, jangkauan dan urutan, diagram Gant; (c) membagi tugas; (d) 


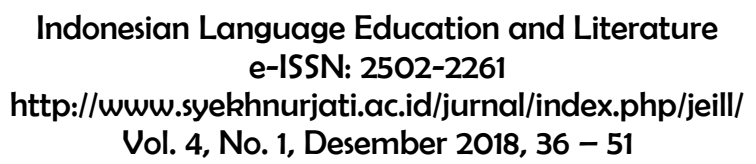

bekerja secara individu atau tim untuk menciptakan materi; (e) membuka sumber data; (f) mempertimbangkan kembali modular dalam paket materi. Artinya, peneliti yang juga pengembang tentu melakukan pengkreasian materi.

6) Teaching. Pada tahap ini, ada tiga hal yang dilakukan. Pertama adalah uji coba atau percobaan materi (pilot materias). Setelah itu, dilanjutkan dengan mendiskusikan hasil uji coba (discuss their effectiveness). Lalu, dilakukan revisi.

7) Evaluating 'mengevaluasi'. Pada bagian akhir, ada lima hal yang dapat dilakukan: 1) melakukan evaluasi terhadap materi yang sudah dimiliki; 2) merevisi materi yang sudah dievaluasi; 3) menciptakan fomat materi yang dapat bertahan lama; 4) mempublikasikan materi; 5) secara terus menerus mengembangkan materi. Pengembang melakukan revisi materi setiap dilakukan uji coba (3 kali uji coba).

Dari ketujuh tahapan yang dikemukan Brown tersebut, ada tiga tahapan pokok (central).Pertama adalah creating 'mengkreasikan'. Kedua adalah teaching 'mengajarkan'. Ketiga adalah evaluating 'mengevaluasi'. Semua tahap itu dapat diterapkan dalam pengembangan materi ajar bahasa Indonesia bagi penutur asing.

\section{Model Jolly dan Bolitho}

Dibandingkan model Tomlinson dan model Brown, jumlah fase/tahap pengembangan pada model Jolly dan Bolitho (2011) sama dengan model Brown. Pada model ini juga terdapat tujuh tahap yang mesti dilakukan dalam pengembangan materi ajar: 1) mengidentifikasi kebutuhan materi, 2) mengeksplorasi kebutuhan, 3) realisasi kontekstual materi, 4) realisasi pedagogik materi, 5) produk materi, 6) peserta didik yang menggunakan materi, dan 7) evaluasi materi sesuai tujuan.

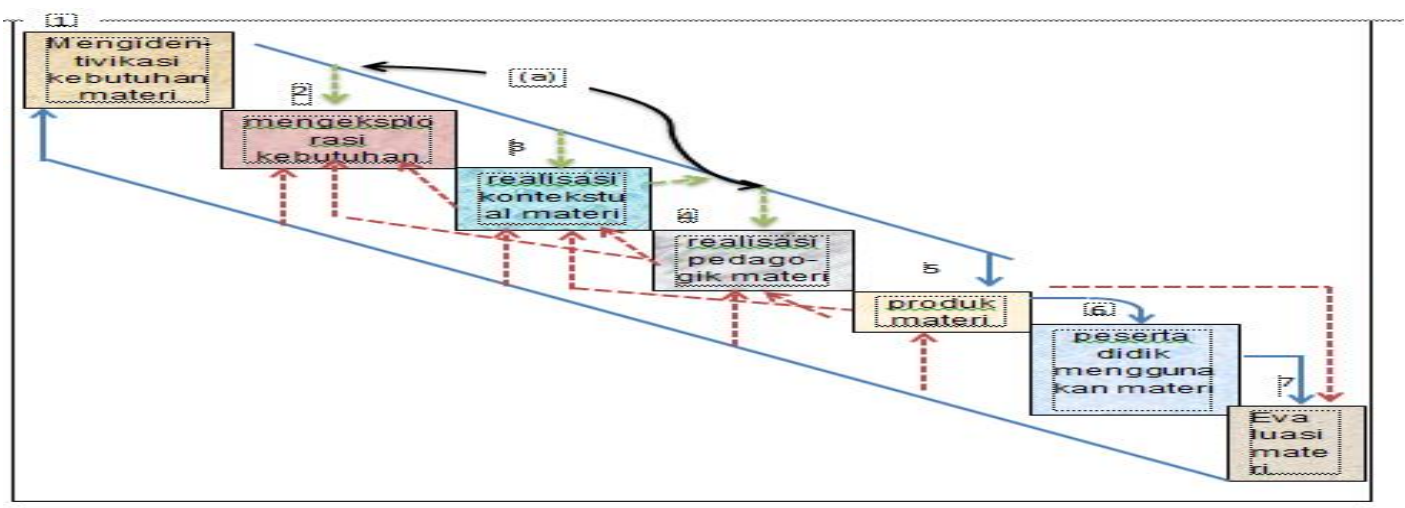

Gambar 5. Model Jolly dan Bolitho (2011: 113)

\section{MODEL YANG DIMODIFIKASI}




\section{Indonesian Language Education and Literature e-ISSN: 2502-2261 \\ http://www.syekhnurjati.ac.id/jurnal/index.php/jeill/ Vol. 4, No. 1, Desember 2018, 36 - 51}

Dari delapan model pengembangan materi ajar di atas, dapat dipadukan menjadi tiga tahap besar, yakni 1) tahap persiapan, 2) tahap perencanaan dan 3) tahap pengembanganevaluasi. Alasan digabungkannya tahap pengembangan dengan tahap evaluasi adalah setelah dilakukan penelitian, kedua tahap itu dilakukan bersamaan. Di saat dilakukan evaluasi, saat itu pula dilakukan revisi. Revisi itu berarti melakukan pengembangan.

Dari tiga tahap besar ini diuraikan lagi menjadi tujuh belas tahap. Ketujuh belas tahapan itu telah dilakukan selama penelitian dan pengembangan. Tahapan itu adalah sebagai berikut: 1) kurikulum yakni menganalisis kurikulum BIPA secara umum, 2) analisis kebutuhan, 3) silabus, 4) pengumpulan teks-teks berupa karya sastra (puisi, dogeng), lagu, pengumuman, buku, berita di internet, acara televisi, dan film animasi serta dokumenter, 5) pemilahan teks-teks, 6) pengkreasian materi, 7) draf I, 8)penyusunan soal tes, 9) uji one to one (pakar dan peserta didik BIPA) menggunakan instrumen kuesioner dan wawancara, 10)revisi I, 11) draf II, 12) uji coba kelompok kecil dengan menggunakan draf II (instrumen pedoman observasi, kuesioner dan wawancara), 13) revisi II, 14) draf III, 15) uji efektivitas (instrumen nilai tes awal dan tes akhir, pedoman observasi, kuesioner, dan wawancara) menggunakan draf III, 16) revisi III, dan 17) produk final.

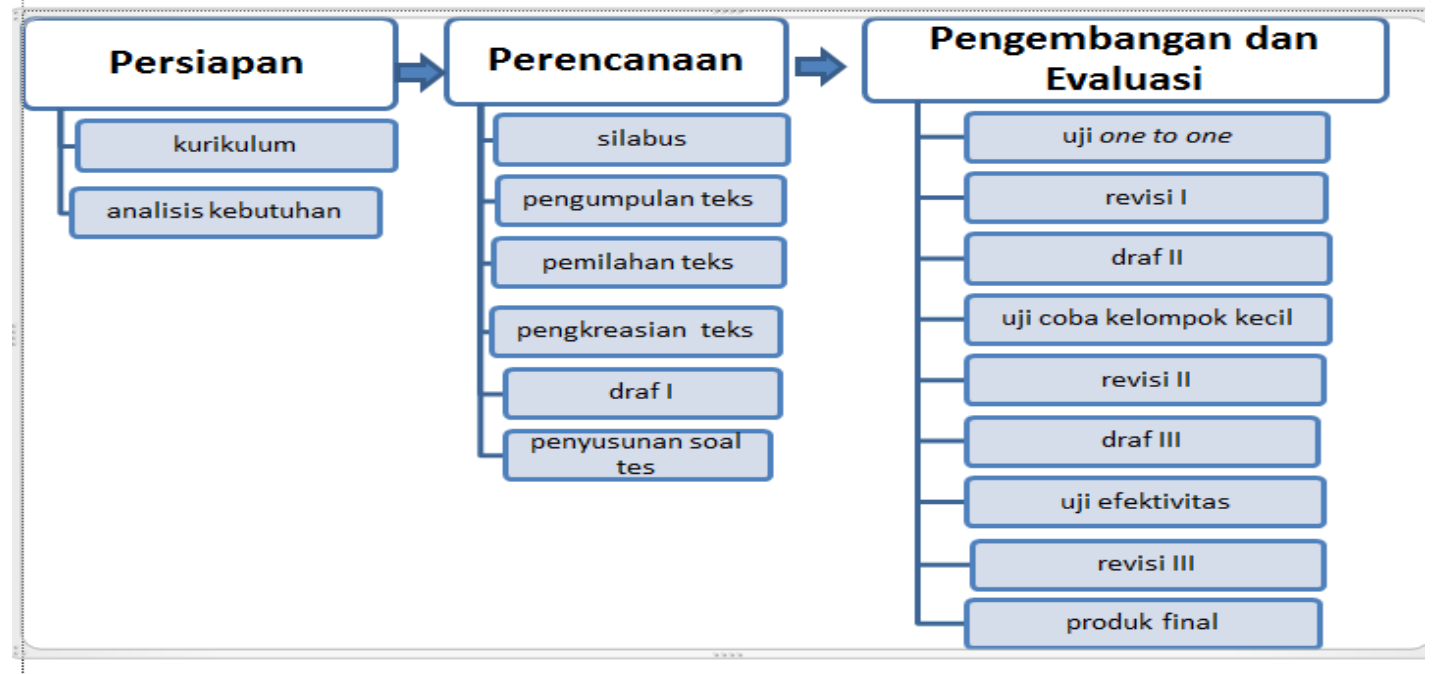

Gambar 6. Model yang dimodifikasi

Alasan adanya modifikasi adalah pada model Tomlinson yang tahap ke-1 (pengumpulan teks) dan ke-2 (pemilihan teks) akan lebih baik dilakukan jika terlebih dahulu dilakukan tahap ke-1 (kurikulum), ke-2 (analisis kebutuhan), dan ke-3 (tujuan umum dan khusus) pada model Brown dan tahap ke-1 (identifikasi kebutuhan materi) pada model Kemp, model ADDIE dan tahap ke-1serta ke-2 (mengeksplorasi kebutuhan) pada 


\section{Indonesian Language Education and Literature e-ISSN: 2502-2261 \\ http://www.syekhnurjati.ac.id/jurnal/index.php/jeill/ \\ Vol. 4, No. 1, Desember 2018, 36 - 51}

model Jolly dan Bolitho, yakni sebelum melakukan pengumpulan dan penyeleksian materi, terlebih dahulu dilakukan tahap ke-1 kurikulum, ke-2 analisis kebutuhan, dan ke-3 menyusun silabus. Setelah menyusun silabus, dilakukan tahap ke-1 dan ke-2 Tomlinson lalu dilakukan tahap ke-4 pengumpulan dan ke-5 pemilihan dokumen-dokumen materi. Selanjutnya, dilakukan tahap ke-6 pengkreasikan materi itu serta tahap ke-7 memproduksinya menjadi draf I (buku peserta ajar yang berisi tugas dan buku pegangan pengajar). Adanya buku pegangan pengajar sesuai dengan konsep ADDIE bagian ke-3 pengembangan, yakni mengembangkan buku peserta didik dan panduan untuk pengajar. Tahap pengumpulan, pemilihan dan pengkreasian teks-teks yang akan disusun menjadi Draf I ini tidak ada pada ketujuh model, kecuali pada model Tomlinson.

Tahap ke-8 (menyusun soal-soal tes yang akan digunakan untuk tes awal dan tes akhir) berdasarkan tahap ke-4 pada model Brown, tahap ke-3 pada model Borg dan Gall, tahap ke-4 pada model Dick, Carey, dan Carey, tahap ke-2 pada model ADDIE, yakni mendesain bentuk tes. Tahap ke-9 (menerapkannya/uji coba) ada pada model Jolly dan Bolitho bagian ke-6 (mempersiapkan peserta didik yang menggunakan materi), pada model Tomlinson tahap ke-3, model ADDIE tahap ke-4, model Dick, Carey, dan Carey tahap ke-8, model Borg dan Gall tahap ke-4, pada model Brown tahap ke-6 dan model ASURE tahap ke-5. Pada tahap ke-9 ini dilakukan uji one to one, teks yang sudah dipilih dan disusun menjadi materi ajar (draf I) dibaca dan dinilai oleh pakar dan peserta didik yang telah pernah mendapatkan pelajaran BIPA.Pakar sebaiknya ganjil, minimal ada pakar kurikulum, BIPA, dan linguistik. Pakar dan peserta didik diberikan kuesioner tentang evaluasi materi ajar dan diwawancarai. Khusus untuk pakar, hal yang dinilai ini ada tiga, yakni buku peserta didik, buku pegangan pengajar, dan silabus. Hasil dari kuesioner dan wawancara dijadikan pedoman untuk melakukan revisi I (revisi silabus dan materi ajar [buku peserta didik dan buku pengajar]).

Tahap ke-10 sampai ke-16 digolongkan tahap pengembangan dan evaluasi dan tahap ini sesuai model Brown tahap ke-7, model Jolly dan Bolitho tahap ke-7, model Tomlinson tahap ke-6, ke-7, dan ke-8, model Kemp tahap ke-8 dan ke-9, model ADDIE tahap ke-3 dan ke-5, model Dick, Carey, dan Carey tahap ke-8 dan ke-9, model Borg dan Gall tahap ke-8 dan ke-9, dan model ASURE tahap ke-6.

Pada uji kelompok kecil, materi yang digunakan adalah materi yang sudah direvisi pada revisi I. Materi revisi I (draf II) itu dibaca dan dipelajari oleh peserta didik dan 


\section{Indonesian Language Education and Literature e-ISSN: 2502-2261 \\ http://www.syekhnurjati.ac.id/jurnal/index.php/jeill/ \\ Vol. 4, No. 1, Desember 2018, 36 - 51}

dipelajari oleh teman sejawat. Teman sejawat mempraktikkan materi itu di di dalam kelas (minimal 1 tema). Saat uji coba kelompok kecil ini, pengembang mengamati prosesnya dengan berpedoman pada pedoman observasi. Setelah diujikan beberapa tema, pengembang meminta teman sejawat dan peserta didik yang mempraktikkan materi ajar tersebut dengan mengisi kuesioner. Lalu, dapat dilanjutkan dengan wawancara. Hasil dari observasi, kuesioner, dan wawancara dijadikan pedoman untuk melakukan revisi II (merevisi silabus, buku peserta didik dan pengajar). Pada tahap ini mesti diperhatikan juga penggunaan alat evaluasi berupa tes yang telah disusun pada tahap ke-8. Alat mengukur kemajuan siswa berupa tes ini sudah dipersiapkan sesuai dengan jumlah tema yang akan diujicobakan. Jika tema yang akan diujicobakan untuk uji kelompok kecil sama dengan uji efektivitas, misalnya 3 tema (tema 1-3), alat tes itu pun mesti untuk tema 1-3 itu juga.

Pada uji keefektifan, materi revisi II (draf III) itu dibaca dan dipelajari oleh peserta didik yang berbeda dengan peserta didik pada uji kelompok kecil. Pada uji keefektifan ini sebaiknya separuh dari jumlah tema diujikan. Misal, jika temanya ada 10, dapat diujiefektifkan 5 tema. Semakin banyak tema yang diujiefektifkan semakin banyak ditemukan kelemahan-kelemahan dari materi ajar yang dikembangkan. Sebelum dilakukan uji keefektifan, peserta didik dites terlebih dahulu. Pada akhir uji keefektifan, juga dilakukan tes akhir. Soal yang digunakan pada tes awal sama dengan soal yang digunakan pada tes akhir. Hasil uji keefektifan ini dijadikan dasar melakukan revisi III (merevisi silabus, buku peserta didik dan pengajar) di samping hasil observasi, wawancara, dan pengisian kuesioner oleh peserta didik. Dari revisi III inilah disusun model final.

Adanya pengisian kuesioner dan wawancara sebagai penilaian oleh peserta ajar untuk setiap draf sangat diperlukan. Setiap peserta ajar yang diminta mengisi kuesioner dan menjawab pertanyaan saat diwawancarai akan memberikan penilaian yang berbedabeda. Intinya, semakin banyak peserta ajar yang menilai, semakin banyak pula masukan untuk perbaikan model yang dikembangkan. Alasannya lainnya, peserta ajar adalah pihak pengguna model yang dikembangkan.

\section{SIMPULAN}

Berdasarkan tujuan penulisan dapat disimpulkan bahwa setiap model itu memiliki kelebihan dan kekurangan. Ada tahapan-tahapan yang sama pada kedelapan model itu dan ada juga perbedaaannya. Dengan demikian, pengembangan model materi ajar bahasa 


$$
\begin{gathered}
\text { Indonesian Language Education and Literature } \\
\text { e-ISSN: 2502-2261 } \\
\text { http://www.syekhnurjati.ac.id/jurnal/index.php/jeill/ } \\
\text { Vol. 4, No. 1, Desember 2018, } 36 \text { - } 51
\end{gathered}
$$

Indonesia bagi penutur asing dapat dilakukan dengan mengombinasikan model-model penelitian pengembangan yang sudah dirumuskan para pakar. Dari delapan model yang dianalisis, dapat dirumuskan model yang telah dimodifikasi dan ada tiga bagian utamanya, yaitu 1) pendahuluan, 2) perencanaan, dan 3) pengembangan-evaluasi. Dari 3 bagian itu dapat diuraikan menjadi 17 bagian: 1) kurikulum, 2) analisis kebutuhan, 3) silabus, 4) pengumpulan teks, 5) pemilahan teks, 6) pengkreasian materi, 7) draf I, 8) penyusunan soal tes, 9) uji one to one, 10) revisi I, 11) draf I, 12) uji coba kelompok kecil, 13) revisi II, 14) draf II, 15) uji efektivitas, 16) revisi III, dan 17) produk final.

\section{DAFTAR PUSTAKA}

Borg, W. R. \& Gall, M. D. (1983). Educational Research: An Introduction. $4^{\text {th }}$ Edition. New York: Longman.

Branch, R. M. (2009). Instructional Design: The ADDIE Approach. New York: Springer.

Brinton, D. M. (2001). "The Use of Media in Language teaching", dalam Celce-Murcia, ed, Teaching English as a Second or Foreign Language. Singapura: Tomson Learning.

Brown, H. D. (2007). Teaching by Principles: An Interactive Approach to Language Pedagogy. San Francisco: Longman.

Dick, W., Carey, L. \& Carey, J. O. (2009).The Systematic Design of Instruction. $7^{\text {th }}$ Edition. Ohio: Pearson.

Gay, L. R., Mills, G. E. \& Airasian, P.W. (2011). Educational Research: Competencies for Analysis and Applications. $10^{\text {th }}$ Edition. London: Pearson.

Gustafson, K. L. \& Branch, R. M. (2002). Survey of Instructional Development Model.New York: ERIC.

Morrison, G. R., Ross, S. M., Kemp, J. E. \& Kalman, H. (2007). Designing Effective Instruction. $5^{\text {th }}$ Edition. USA: John Wiley \& Sons, Inc.

Prastowo, A. (2014). Pengembangan Bahan Ajar Tematik: Tinjauan Teoretis dan Praktik. Jakarta: Kencana Prenadamedia group.

Pribadi, B. A. (2010).Model Desain Sistem Pembelajaran. Jakarta: Dian Rakyat.

Richards, J. C. (2001). Curriculum Development in Language Teaching. Cambridge: Cambridge University Press.

Richey, R. C., Klein, J. D. \& Tracey, M. W. (2011). The Instructional Design Knowledge Base: Theory, Research, and Practice. New York: Routledge.

Setyosari, P. (2012). Metode Penelitian Pendidikan dan Pengembangan. Cetakan ke- 2. Jakarta: Kencana Prenada Media Group.

Shambaugh, N \& Magliaro, S. G. (2006). Instructional Design: A Systematic Approach for Reflective Practice. San Francisco: Pearson. 


$$
\begin{gathered}
\text { Indonesian Language Education and Literature } \\
\text { e-ISSN: } 2502-2261 \\
\text { http://www.syekhnurjati.ac.id/jurnal/index.php/jeill/ } \\
\text { Vol. 4, No. 1, Desember 2018, } 36 \text { - } 51
\end{gathered}
$$

Smaldino, S. E., Lowther, D. L. \& Russell, J. D. (2006). Instructional Technology and Media for Learning. $9^{\text {th }}$ edition. Ohio: Pearson.

Sugiyono. (2014). Metode Penelitian Kuantitatif dan Kualitatif dan R\&D. Cetakan ke-20. Bandung: Alfabeta.

Tomlinson, B. Ed. (2007). Developing Materials for Language Teaching. London: Continum, The Tower Building.

Zahidin, M. A. \& Mulyaningsih, I. (2016). Teori Koneksionisme dalam Pembelajaran Bahasa Kedua Anak Usia Dini. Indonesian Language Education and Literature, 1(2), 207 - 220. DOI: http://dx.doi.org/10.24235/ileal.v1i2.599. 